\title{
A SZOVJET PSZICHOLÓGIA AMERIKAI INTERPRETÁCIÓJA AZ EMIGRÁNSOK VISSZAEMLÉKEZÉSEI ALAPJÁN
}

\author{
SOMOGYVÁRI LAJOS \\ Pannon Egyetem MFTK Tanárképző Központ
}

\begin{abstract}
A Harvard Egyetem Orosz Kutatási Központja egyedülálló projektet valósított meg 1949 és 1953 között, több száz szovjet emigráns életútinterjújának rögzítésével. A szociológiai indíttatású beszélgetések angol átiratban maradtak fenn, az adatbázis elérhető online (Harvard Project on the Soviet Social System). Magyarországon nem elemezték még az 1917 és 1945 közötti szovjet hétköznapokról tanúskodó anyagot, mely két részre tagolódik: A-jegyzék (személyes élettörténetek), B-jegyzék (speciális témák). Tanulmányom mindkét összeállításból merítve mutatja be, hogy milyen kép rajzolódott ki a pszichológia és pszichiátria helyzetéről az adatközlők és rögzítők interaktív összjátékában: tanárok, klinikai pszichológusok, pszichiáterek beszélnek szakmáról és annak politikai felhasználásáról.
\end{abstract}

Kulcsszavak: kommunista nevelés, emigránsok, interjú, Harvard Project on the Soviet Social System, narratívaelemzés, oral bistory

A unique project was developed between 1949 and 1953 by the Harvard University Russian Research Center, based on hundreds of interviews recorded with Soviet emigrants, conducted by sociologists. The organized system of transcripts, transcribed into English, are available online (Harvard Project on the Soviet Social System). These interviews reflect everyday Soviet reality between 1917 and 1945, and they have not yet been analysed in Hungary. The corpus is constituted by two parts: A-Schedule (personal life stories) and B-Schedule (special topics). Based on both, I give an acount of the positions of Stalinist psychology and psychiatry, as created in the interactions of the emigrants and the interviewers, in which teachers, clinical psychologists and psychiatrists spoke about their profession placed in the dimension of the political situation.

Keywords: communist education, emigrants, interview, Harvard Project on the Soviet Social System, narrative analysis, oral history

Levelező szerző: Somogyvári Lajos, Pannon Egyetem MFTK Tanárképző Központ, 8200 Veszprém, Egyetem u. 10. E-mail: tabilajos@gmail.com 


\section{A kutatás előfeltevései}

$\mathrm{T}$ anulmányom a szovjet pszichotudományok (neurológia, pszichológia, pszichiátria, pszichotechnika - a lélek átalakítását megcélzó, alkalmazott pszichológia) amerikai percepcióját mutatja be a kezdődő hidegháború kontextusában, különleges forráscsoportra alapozva. Többszörös transzformációkon keresztül átment narratívákkal van itt dolgunk: azt a módot fogjuk látni, ahogyan a kialakuló bipoláris világrendben a nyugati világ vezető hatalma a megszerezhető, rendelkezésre álló információkból értelmezési kereteket alkotott, hogy előnyt szerezzen a kommunista rendszerrel szemben. Az elemzésben a pedagógiai dimenzió háttérbe szorul, a pszichológia felhasználási területei kerülnek fókuszba: megfigyelhetjük a kommunista logikai sémák által közvetített politikai dominanciát, mely bizonyos területeket és ezek képviselöit bűnösként bélyegzett meg, kiszorított; míg mások nevét és nézeteit saját céljai elérésére értelmezett át és propagált.

$\mathrm{A} z$ amerikaiak egyik legfőbb célja az ellenség megismerése volt, ami egy új tudásterület, a szovjetológia létrejöttét eredményezte (Engerman 2009) - az intézményesülésben a Harvard Orosz Kutatási Központja és az interjúkat eredményező projekt (Harvard Project on the Soviet Social System, továbbiakban rövidítve: HPSSS) rendkívül nagy szerepet játszott. A szovjetológia jelentette a szürőt, amin keresztül a vasfüggöny mögötti országokat és a Szovjetuniót „lefordították” saját maguk számára az USA politikai döntéshozói, szakemberei - ehhez kapcsolódnak a kutatást megalapozó előfeltevéseim: 1. Első olvasatban a szovjet pszichotudományokról szóló amerikai véleményeket ismerhetjük meg, áttételesen a két világháború közötti szovjet valóságról is kapunk egyfajta látleletet.

2. A hidegháború egyre élesedő légkörében valamennyi, korábban csak a szakma által uralt terület átpolitizálódott: a Szovjetunióban és a szatellitországokban a politika döntötte el, hogy mi a szakma.

3. Az amerikai tudósok és hivatalnokok a kommunista rendszer müködési logikáját és sebezhető pontjait igyekeztek feltárni.

4. Mindez találkozott a legfőbb információforrásnak számító emigránsok elképzeléseivel, hiszen feltételezhetően a rendszer üldözöttjeiként menekültek Nyugatra, a Szovjetunió szempontjából ellenségként/árulóként adtak beszámolót az amerikaiaknak.

\section{Egy különleges forráscsoport}

A HPSSS jól feltárt az angolszász világban, online is elérhető, ${ }^{1}$ Magyarországon viszont nem nagyon bukkant fel eddig a társadalomtörténeti diskurzusokban. 1945 után több ezer szovjet állampolgár maradt a nyugati szövetségek által megszállt európai térfélen, akik különböző okokból nem akartak hazatérni, így hontalan személyek (displaced persons) lettek - ők váltak a kutatás „alapanyagává” (Edele 2007: 353). 1949-ben kez-

1 https://library.harvard.edu/collections/hpsss/index.html. A kutatás elején, 2020 februárjában ezek az interjúk még teljesen hozzáférhetők (és letölthetők) voltak online, az írás időpontjában, 2020 júliusában viszont már nem minden. 
dődött a munka, mikor Merle Fainsod és Paul Friedrich próbainterjúkat vettek fel Münchenben - mindkét kutató a Harvardhoz kötődött, Fainsod szovjetológusként szerzett magának hírnevet, a harmincas években ösztöndíjas volt a kommunizmus hazájában (Pipes 1979); Friedrich antropológiai területen dolgozott, nyelvi képességei miatt alkalmazták kihallgatóként Nyugat-Németországban. ${ }^{2}$

A korszakra jellemző volt az akadémiai szféra és a kormányzati-hadiipari komplexum intézményi és személyi szintü összefonódása az USA-ban, nem véletlen, hogy a Harvard Orosz Kutatási Központja a Maxwell Légibázishoz tartozó Human Resources Research Institute-tal (HRRI) kötött szerződést, mely anyagi hátteret nyújtott a projekthez 1950 és 1953 között (Mandelstam 1980: 1). A légierő a társadalomtudományos kutatásokat egyébként a pszichológiai hadviselésben és nukleáris stratégiai tervezésben kívánta felhasználni (This is Your Air Force 1951).

1950 és 1953 között Ausztriában, az NSZK-ban és az USA-ban a téma szakértői vették fel az interjúkat, a szociológus Alex Inkeles és a szociálpszichológus Raymond Bauer által kidolgozott szigorú módszertan felhasználásával. Több mint ezer emigránssal vették fel a kapcsolatot, majd 330 személyt válogattak ki, végeredményként 343 életútinterjút (A-Schedule) és 362 speciális témában készült beszélgetést (B-Schedule) rögzítettek. A digitalizált adatbázisban ez a két fö forráscsoport és a hozzátartozó segédanyagok találhatók meg, minden fontosnak vélt információt kategóriákba és alkategóriákba soroltak, számsorokká kódoltak és listákba indexeltek, hogy utána lehessen keresni, az A-Schedule esetében ez 33 fö kategóriát jelent (1. 1. kép).

A munkával, családdal, oktatással, lakhatással kapcsolatos tapasztalatok, vélemények és viszonyulások, az életmódról, egészségügyi állapotról, politikai orientációról, vallásosságról tett megállapítások is megjelentek a szempontok között, melyeket utólagos beírások egészítettek ki. Ezek közül a legfontosabb a 001 Personal data (személyes adatok), hiszen ehhez 1745 külön akta tartozik (A-Schedule Face Sheet Data Book), ami jelzi az összes interjú számát. Feltételezhető, hogy az A- és B-Schedule között nagyfokú az átfedés, de ennek pontos megállapításához további kutatás szükséges. A speciális témákról szóló sorozat (B-Schedule) kevesebb kategóriára oszlik: gazdasági, családi, kormányzati, nemzetiségekkel, háborús megszállással, a partizán hadviseléssel, speciális esetekkel, klinikai interjúkkal és társadalmi rétegződéssel kapcsolatosak. Az utolsó, B11-gyel jelölt kód a szakmákról szól (Professions), itt például pszichológusok, pszichiáterek vallottak pályaszocializációjukról, a szakma elismertségéről és tudományos-politikai vitákról.

Az interjúk tapasztalatait feldolgozták, viszont az amerikaiak is felismerték a módszer és a vizsgálati szituáció korlátaiból eredő torzítási lehetőségeket: a volt szovjet állampolgárok negatív érzelmeit (félelem, szégyenérzet, gyanakvás a nyugatiakkal szemben), saját elöítéleteiket stb. Ennek érdekében adták ki 1953-ban a szovjet menekültek interjúztatásának kézikönyvét (1. 2. kép), amiböl kiderül, hogy a válaszadók vagy a háború alatt hontalanná vált polgári személyek voltak, vagy a szovjet megszálló haderőt elhagyó katonák, akik átmentek a nyugati zónába; többségük menekülttáborokban tartózkodott, mikor önkéntesen nyilatkoztak.

Guide to the Paul Friedrich Papers, 1945-1999. Chicago, University of Chicago Library, 2015. https:// www.lib.uchicago.edu/e/scrc/findingaids/view.php?eadid=ICU.SPCL.FRIEDRICHP [Letöltve: 2020. 07. 23.] 


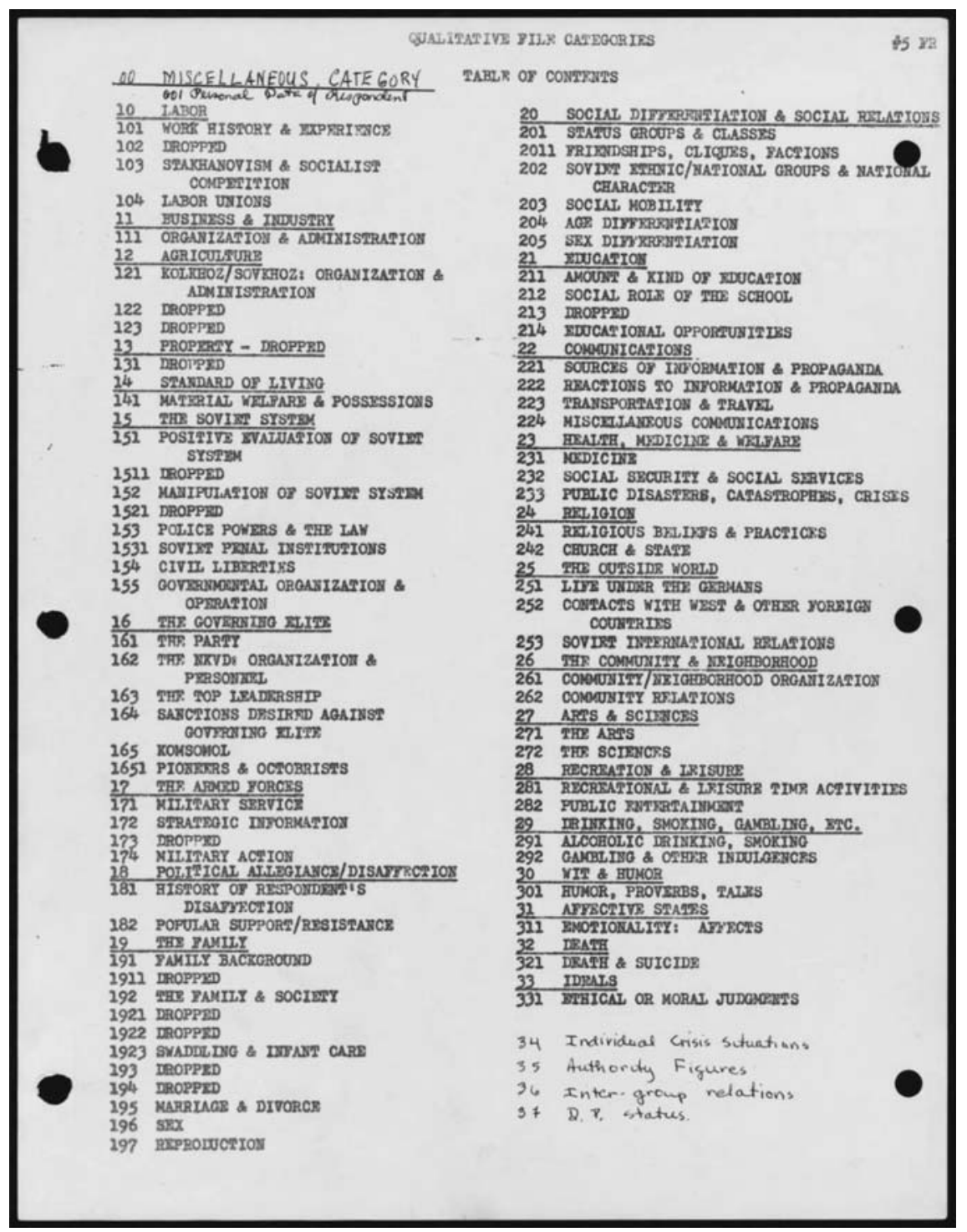

1. kép: A-Schedule, személyes életinterjúk kategóriái (Qualitative File Manual... 1953)

\section{Elméleti-módszertani háttér}

A HPSS-t felhasználó mai történészek többsége az interjúkra „tények gyűjtőhelyeként” („depositories of fact”) tekint, ez a megközelítés azonban figyelmen kívül hagyja a dokumentumok létrejöttének folyamatát (Prendergast 2017: 19). Nemcsak az amerikaiak intenciói alakították ezt, hanem a szovjetek aktív emlékező tevékenysége, a múltat újrakonstruáló, utólagos értelmező munkája, megfelelési szándékai, nem beszélve az átírások, szelekció, hangsúlykiemelések ma már visszakövethetetlen lépéseiről. Ezzel függ össze a kérdés a mások által, korábban létrehozott interjúarchívumok újrafelhasz- 


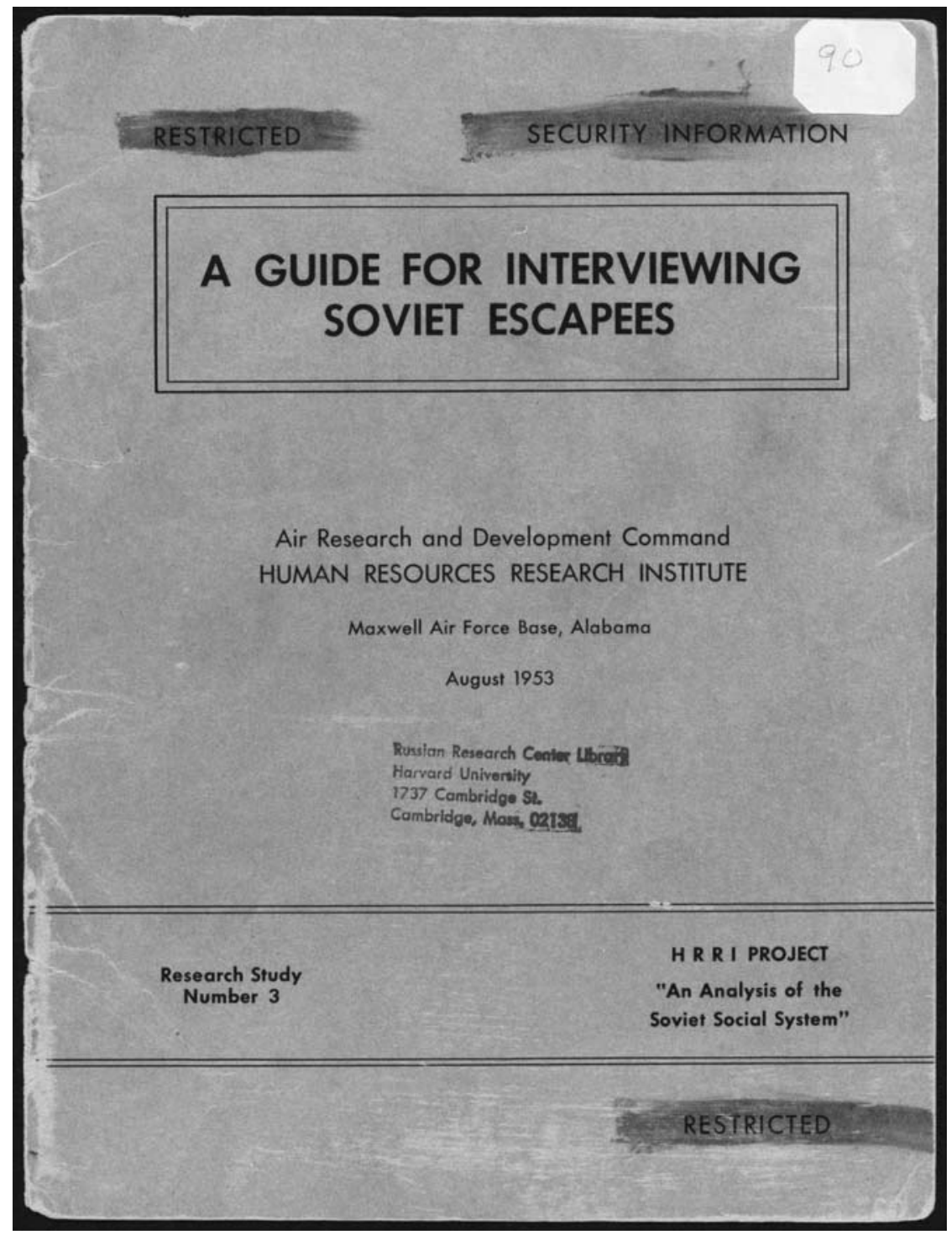

2. kép: Útmutató a szovjet menekültek interjúztatásához (Bauer 1953)

nálására vonatkozóan: ezekben az esetekben a saját kérdésfeltevéseinknek megfelelően rekontextualizálunk egy olyan forrásanyagot, aminek a létrehozásában nem vettünk részt, és ami már egy eleve adott értelmezési keretet jelent (Tureby 2013). Tanulmányomban a rekontextualizálás munkája a már ismertetett előfeltevések alapján kezdődött meg. Az alábbi technikai lépések jelentették a kiindulópontot.

A kutatás alapjául szolgáló korpusz létrehozása kétlépcsős folyamat eredménye volt:

1. A psych* keresőszóval az összes, pszichológiával kapcsolatos kifejezést tartalmazó dokumentum kigyüjtésre került (490 említés, ami 218 különböző interjúban szerepelt), ezt követően 
2. azokat az önálló elemzéseket, alfejezeteket szűrtem ki, amelyekben a dokumentum kulcstémája valamely pszichotudomány ( 9 item). Az első táblázat bemutatja a legfontosabb információkat az elemzés alapjául szolgáló 9 interjúhoz.

1. táblázat: Az elemzés alapjául szolgáló korpusz (a szerző szerkesztése)

\begin{tabular}{|c|c|c|c|c|}
\hline Név & Foglalkozás & Időszak & Topik & Dokumentum \\
\hline Mr. Soloviev & N/A & N/A & $\begin{array}{l}\text { pszichológia a tömeg- } \\
\text { kommunikációban, } \\
\text { propagandában }\end{array}$ & $\begin{array}{l}\text { B-Schedule, } \\
\text { Vol. 2. Case } 359\end{array}$ \\
\hline $\begin{array}{l}\text { Nikolaus } \\
\text { Wetlugin }\end{array}$ & $\begin{array}{l}\text { tesztelö, instruk- } \\
\text { tor }\end{array}$ & $1928-1933$ & $\begin{array}{l}\text { pszichológiai tesztelés a } \\
\text { termelésben }\end{array}$ & $\begin{array}{l}\text { B-Schedule, } \\
\text { Vol.2. Case } 382\end{array}$ \\
\hline $\begin{array}{l}\text { Professor } \\
\text { Vashchenko }\end{array}$ & egyetemi tanár & $\begin{array}{l}\text { 1917- } \\
\text { II. világháború }\end{array}$ & $\begin{array}{l}\text { pszichológiai tesztelés, } \\
\text { iskolák és viták }\end{array}$ & $\begin{array}{l}\text { B-Schedule, } \\
\text { Vol. } 13 .\end{array}$ \\
\hline Dr. Hirsch & orvos & II. világháború & $\begin{array}{l}\text { pszichotechnikai intézet } \\
\text { (Kijev) }\end{array}$ & $\begin{array}{l}\text { B-Schedule, } \\
\text { Vol. 13, Case } 374\end{array}$ \\
\hline $\begin{array}{l}\text { Professor } \\
\text { Shumilin }\end{array}$ & egyetemi tanár & $1928-1936$ & pszichotechnika, tesztelés & $\begin{array}{l}\text { B-Schedule, } \\
\text { Vol. 21, Case } 39\end{array}$ \\
\hline N/A & $\begin{array}{l}\text { professzor, kuta- } \\
\text { tóintézet vezetője }\end{array}$ & $1917-1942$ & $\begin{array}{l}\text { a szovjet pszichiátria } \\
\text { helyzete, fejlődéstörténete }\end{array}$ & $\begin{array}{l}\text { A-Schedule, } \\
\text { Vol. 4, Case } 40\end{array}$ \\
\hline N/A & orvos, pszichiáter & $1927-1940$ & $\begin{array}{l}\text { munka a kijevi ideg- } \\
\text { klinikán }\end{array}$ & $\begin{array}{l}\text { A-Schedule, Vol. } \\
11 \text {, Case } 139\end{array}$ \\
\hline N/A & orvos & $\begin{array}{l}\text { 1921- } \\
\text { II. világháború }\end{array}$ & $\begin{array}{l}\text { pályaszocializáció, } \\
\text { pszichiáteri munka }\end{array}$ & $\begin{array}{l}\text { B-Schedule, } \\
\text { Vol. 21, Case } 139\end{array}$ \\
\hline N/A & orvos, pszichiáter & $1917-1930$ & $\begin{array}{l}\text { pályaszocializáció, } \\
\text { kutatói-klinikai munka }\end{array}$ & $\begin{array}{l}\text { B-Schedule, } \\
\text { Vol. 21, Case } 424\end{array}$ \\
\hline
\end{tabular}

Feltűnő a psych* kezdetű szavak gyakori előfordulása, aminek két fö oka lehet: a kutatás szakmai háttere és (szociál)pszichológiai érdeklődése, a szovjet mentalitás feltérképezése nyújtja az egyik magyarázati lehetőséget. A kiválasztott szovjet emberek társadalmi összetétele jelenti a másik opciót, hiszen többségében értelmiségi foglalkozásúakat választottak ki, akik vezető beosztásban voltak, a nyelvhasználatuk is szofisztikáltabb lehetett más kortárs forrásokéhoz képest. Mindez természetesen csak feltevés, hiszen nem végeztem eltérő kifejezésekkel ellenpróbát, illetve a dokumentumok készítését alakító, ismert tényezők szintén befolyásolhatták az eredményt. Az interjúzás pszichológiai dimenziója - ami az amerikaiak számára is világos volt és egy külön írás témája lehetne - mindenesetre rányomta a bélyegét a végeredményre.

$\mathrm{A} z$ első táblázat összefoglalja az elemzésre kiválogatott korpusz főbb jellemzőit: elsőként a neveket, melyek közül a speciális témákban meghallgatott személyek neve ismert, míg a pszichiáterekkel végzett, teljes életutakat átfogó interjúk anonimizáltak. A foglalkozást tekintve látható, hogy főleg az akadémiai-egészségügyi és oktatásügyi szférában dolgozó értelmiségiekről van szó, akik a II. világháború folyamán kerültek külföldre és maradtak Nyugaton. A topik a narratíva általam meghatározott tematikai fókuszát jelöli, mely a pszichológia alkalmazott jellegét helyezi előtérbe a kérdezők szándékai szerint. A narratíva oktatástörténetben való felhasználása az elbeszélés mód- 
jára, közvetetten az emberi szándékok és érdekek (buman agency) megismerésére helyezi a hangsúlyt (Tamura 2011), a hazai neveléstudományban több példa van már a hasonló megközelítésre (Balog-Szabolcs 2019).

Jelen esetben szerencsés helyzetben vagyunk, mert nemcsak az adatfelvétel és rögzítés, hanem az értelmezés kerete is adott, hiszen 1956-tól megjelentek azok a könyvek, amelyek az interjúkat felhasználva megadták a szovjet emberről, rendszerről és orvoslásról alkotott amerikai narratíva kereteit (Bauer-Inkeles-Kluckhobn 1956; Field 1957; Inkeles-Bauer 1959). Ennek a gondolkodásmódnak a két kulcsfogalma a szovjet típusú totalitariánus rendszer és megvalósítása, illetve az ipari társadalom, az erőszakos modernizáció folyamata (Edele 2007). Az amerikaiak előfeltevéseit követve az alábbi hipotetikus elemzési szempontokat állítottam fel a kutatás kezdetén:

1. A pszichológia alkalmazott, eszközjellege domborodik ki a forrásokból, mely politikai és gazdasági céloknak alárendelt.

2. A pszichotudományokra jellemző a szakmai kompetenciáktól való megfosztottság, az ideológiai-politikai szféra túlsúlya, az ennek megfelelő determinista szemlélettel, voluntarizmussal és az utólagos, elérni kívánt célok legitimációs erejével párosulva.

Az első szempontot a tesztelési mozgalom (testing movement - a kifejezést a források említik) példáján keresztül fogom bemutatni, míg a másodikat a szakma átpolitizálódásán, a pályaszocializáción, a megemlített pszichológiai iskolák és személyek harcain keresztül tematizálom - az elemzés az első táblázatban felsorolt topikok logikája, két fő fókusza mentén történik.

\section{A húszas-harmincas évek tesztelési mozgalma}

A pszichológia széles körü felhasználásának jó példája volt a tesztelés mint a tudomány egyfajta leegyszerűsítő, a nevelés-oktatás kérdéseit megoldó, illetve a termelés hatékonyságát elősegítő tényezőként történő alkalmazása. A pszichotudományok a húszas-harmincas évek Szovjetuniójában (és nemcsak ott) elsősorban hivatkozási keretet jelentettek, az emberi élet megjavításának, a társadalom átalakíthatóságának optimista szemléletét tükrözték (1. pl. Pléb 2011; Sáska 2011). Az amerikai eredetű módszer, a tesztelés mozgalomszerű időszaka, politikai célú felhasználása egészen az ismert 1936-os, konzervatív sztálinista fordulatig tartott (az intelligenciatesztek kontextusához: Leopoldoff 2014), mikor a pedológiai eltévelyedésről párthatározat született, a burzsoá pszichológusokat, az „értelmetlen tesztek”-et és álmarxista nézeteket elítélve (Sáska 2015: 38). A bezárkózás politikája során ideológiai érvekkel diszkreditálták a tesztelést, ami a rosszabb teljesítményeik miatt munkás- és parasztszármazású diákokat szoríthatott ki az oktatásból - a harmincas évek közepétől leváltott pszichológusok helyét pedig pedagógusok és nevelők vették át.

Az elemzés előtt fontos megemlíteni a nézőpontok keveredését: a szövegek olvasása során nem mindig tudjuk elkülöníteni a szovjet megszólalót és az amerikai értékelést, hiszen az élőbeszéd folyamatos lejegyzését gyakran felváltja egyfajta tartalmi összefoglaló, ez pedig óhatatlanul zavarokhoz vezet az interpretációban. A most következő téma esetében ezenkívül hiányzik a distinkció: nem tudjuk meg, milyen típusú tesztekről van szó, feltételezhetjük, hogy intelligencia-, személyiség-, képesség-, és teljesítményteszteket egyaránt szóba hoznak, amik között egyaránt voltak nyugati 
országokból származó kérdőívek és szovjet (tovább)fejlesztések. Ezen szempontok figyelembevételével kísérlem meg kihámozni a szövegekből a tesztelési mozgalom jellemzőit.

Shumilin professzor a sztálini rendszer felgyorsítását célzó, deklarált politikai-gazdasági célokhoz kötötte a tesztek elterjedését: ${ }^{3}$ 1928-ban, az első ötéves terv bejelentése jelentette szerinte a fordulópontot, mikor a pszichotechnikusoknak rengeteg munkájuk lett (ő ekkor egy közelebbről meg nem nevezett pszichotechnikai laboratóriumban dolgozott) - az igazgatás eszközeiként fö feladatuk a hatékonyságnövelés volt. Ma már nem használjuk a pszichotechnika szóösszetételt (az alkalmazott pszichológia kifejezést viszont igen), a 20. század első felében rendkívül korszerűnek számító szervezetpszichológiai, a termelés hatékonyságának növelését célzó irányzatot értettek alatta (Fekete 1940) - Shumilin szerint egyfajta naiv pszichológia valósult így meg a Szovjetunióban. A felvételin és pályaorientációs tevékenységekben éppúgy jelen volt a teszt, mint a képzés részeként, alkalmassági vagy ellenőrző vizsgálatokon, a gépkocsivezetőknél szimulációs berendezésekkel kiegészítve. A legfőbb probléma a szubjektivitás és a hiányzó módszertan volt - a rövid történeteket alkotó projektív módszerek értékelésére például semmilyen támpontot nem kaptak a tesztelők, leginkább saját benyomásaikat rögzítették a vizsgálat során.

Nagy gondot jelentett a megfelelő képzettség hiánya is, Shumilin elmondása szerint bárki dolgozhatott pszichotechnikusként (ezt az innováció gyors, erőltetett bevezetése, az ezt követő túlkereslet és az egyéb alternatívák kiszorulása egyaránt eredményezhette), ami sok későbbi problémát okozott. A felsőoktatásba bekerülésnél és a munkaerő-elosztásnál is igénybe vették a „szakértők” szolgálatait: így kerülhettek például zenei konzervatóriumba teljesen botfülü hallgatók, hiszen csak a kapacitásokat nézték, gyakran életszerütlen szituációkkal felmérve a jelölteket. Különböző szakmákról professziógramokat kellett alkotniuk megfigyelés útján, jellemző módon a kapcsolótábla-kezelővel illusztrálta ezt Shumilin. A szükséges követelmények listázása feltehetően szintén járhatott következményekkel (gondoljunk csak a normarendszerre), jóllehet ezt nem említette az interjúalany. Az objektívnek és megbízhatónak tekintett tesztelhetőség mély gyökereket eresztett a szovjet köznapi gondolkodásban: az emberek lassan minden kérdés megoldása érdekében pszichotechnikushoz mentek, 1934-ben egy asszony például így fordult Shumilinhez: „Professzor Úr, adjon egy tesztet, hogy el tudjam dönteni, kell-e férjet váltanom vagy sem." évek közepétől kezdett visszaszorulni a tesztelés, 1936. április 16-án a pszichológiai elvekre épülő pedológia „tévelygéseiről” szóló párthatározat pedig véget vetett mindennek, csak néhány helyen, például az 1927 óta halott Behtyerevről elnevezett Intézetben használtak továbbra is teszteket (az orosz neurológia és az objektív pszichológia megalapítója Pavlov mellett Behtyerev volt, 1. Skoromets-Akimenko 2007).

A bukás okaként a pszichotechnikusok rossz munkáját jelölte meg Shumilin, de amerikai kiértékelője szerint ugyanilyen fontos tényezőknek számítottak a tesztelési mozgalom által felvetett ideológiai problémák. Ez utóbbi esetében professzor Budanov véleményére hivatkozik az ismeretlen szakértő, akiről egy másik interjúban tudunk meg

A továbbiak alapjául: B-Schedule, Vol. 21, Case 39.

4 A hasonló, de valamivel korábbi oktatási „reformok” köznapi recepciójához, mindenhatóságukat kiparodizáló, foklkórba kerülésükhöz lásd a Dalton-módszer bevezetését, Kosztya Rjabcev naplójában (Ognyev 1977). 
többet. ${ }^{5}$ A kijevi Munkaelméleti Intézet (Institute of Labor) vezetőjeként Budanovék az 1936-os év után is használtak (igaz, titokban) amerikai eredetű teszteket a soförök szelekciójában - a nyugati mérőeszközök használata pedig biztosan okozhatott ideológiai-politikai zavarokat a tárgyalt időszakban. Az interjúkhoz képest a valóság természetesen összetettebb volt: a teszteket használó pedológusok diagnózist állítottak fel, a pedagógusoknak pedig előírták a terápiát. A gyerekek egy része „fejlesztő” iskolába került, ahol gyógypedagógiai módszereket használtak, ez ellen pedig a szülők tiltakoztak - ez szintén fontos eleme volt a bukásnak.

A bányaiparban háromfajta tesztet használtak: az általános típus mellett a fejlődés mértékét szintén diagnosztizálták képzés közben, illetve a munkaátirányítást megelőző, képzettséget mérő változat is létezett - Nikolaus Wetlugin ezen a gazdasági területen, egy kutatóintézetben dolgozott. ${ }^{6}$ Szerinte már 1933-tól megfigyelhető volt a tesztelés visszaszorulása, amit spontán konfliktus idézett elő a pszichotechnikusok és a társadalom többi rétege között: a tesztelők teljesen determinista nézetével gyakran szembeszálltak a pedagógusok és szülők, akik a gyerekek egyéni motivációit, egyéb tényezőket is figyelembe kívántak venni és nem feltétlenül fogadták el a szakvéleményt (How can you say my child is an idiot?). Wetlugin a húszas évek végére teszi (Shumilinnal egybehangzóan) a tesztek széles körű használatának kezdetét: középiskolákban, laboratóriumokban és különböző munkaállomásokon alkalmazták; az oktatási és ipari minisztériumok körözvényben küldték ki a kötelező teszteket és az utasításokat hozzá. A tét az ember átalakíthatósága, megváltoztathatósága volt, ezt a kontextust pedig egyre inkább a pszichológia és pedagógia konfliktusa határozta meg, ez utóbbi harmincas évekbeli győzelmével.

Az adatközlő szerint a párt fenntartásai vezettek végül a tesztek „bukásához”, az elméletellenesség, a politikai felhasználhatóság és a Blonszkijjal szembeni ellenszenv mind-mind hozzájárult ehhez, de a döntő szerepet Gasztyev, a fordizmus és taylorizmus legfőbb képviselője (a partisan of fordism and taylorism) játszotta a tesztelés elleni támadásban. A később kivégzett Alekszej Gasztyev proletárköltőként, táncmüvészként, a szocialista tudományosságon alapuló munkaszervezés úttörőjeként és a Központi Munkaintézet alapítójaként a hatékonyság és többlettermelés jegyében igyekezett az emberi és gépi folyamatokat egyesíteni (Bailes 1977), a felgyorsított fejlődés mottójával. A z utópikus, modernizációs cél ugyanaz volt, mint a pszichotechnika esetében, csupán az egyik elméletet radikális hirtelenséggel váltotta fel egy másik (ez az éles váltás bizonyíthatja a politika általi irányítottságot a területen).

A kétfajta szemlélet nem állt túl messze egymástól, ahogyan azt Dr. Hirsch előadta a kijevi Pszichotechnikai Intézet munkájával kapcsolatban. ${ }^{7} \mathrm{Az}$ idő- és mozgásvizsgálatok, a tekintet, a reflexek, a távolságtartás mechanikus rögzítése a lehető leghatékonyabb ipari termelést kívánta elősegíteni: a vizsgálatokat végző szakemberek „inkább mérnökök voltak, mint orvosok vagy pszichológusok. A vizsgálati személyt nem emberi létezőként kezelték, hanem egy gép tartozékaként." ${ }^{8}$ A hatékonyság ipar- és társadalom-

\footnotetext{
B-Schedule, Vol. 13.

B-Schedule, Vol. 2, Case 382.

B-Schedule, Vol. 13, Case 374.

8 Zamjatyin már nagyon korán kimutatta ezt a logikát Szovjet-Oroszországban betiltott disztópiája, a $M i$ hasábjain (Zamjatyin 2008).
} 
szervezési szemlélete más területeken is jelentkezett, pszichológusok vizsgálták például a zene hatását a munkára, a politikai beszédek, rádióközvetítések és a propaganda hatását a tömegekre - erről Mr. Soloviev számolt be egy háttérbeszélgetésen, ${ }^{9}$ továbbá egy titkos intézet létezéséről is, ahol a legnagyobb politikai foglyokat őrizték és freudi teóriákat használtak.

\section{A szakma átpolitizálódása}

$\mathrm{A} z$ A- és B-Schedule-ben is találhatóak pszichiáterekkel felvett beszélgetések, ezek esetében nem ismerjük az interjúalanyok nevét: két életútinterjú és két speciális témában,

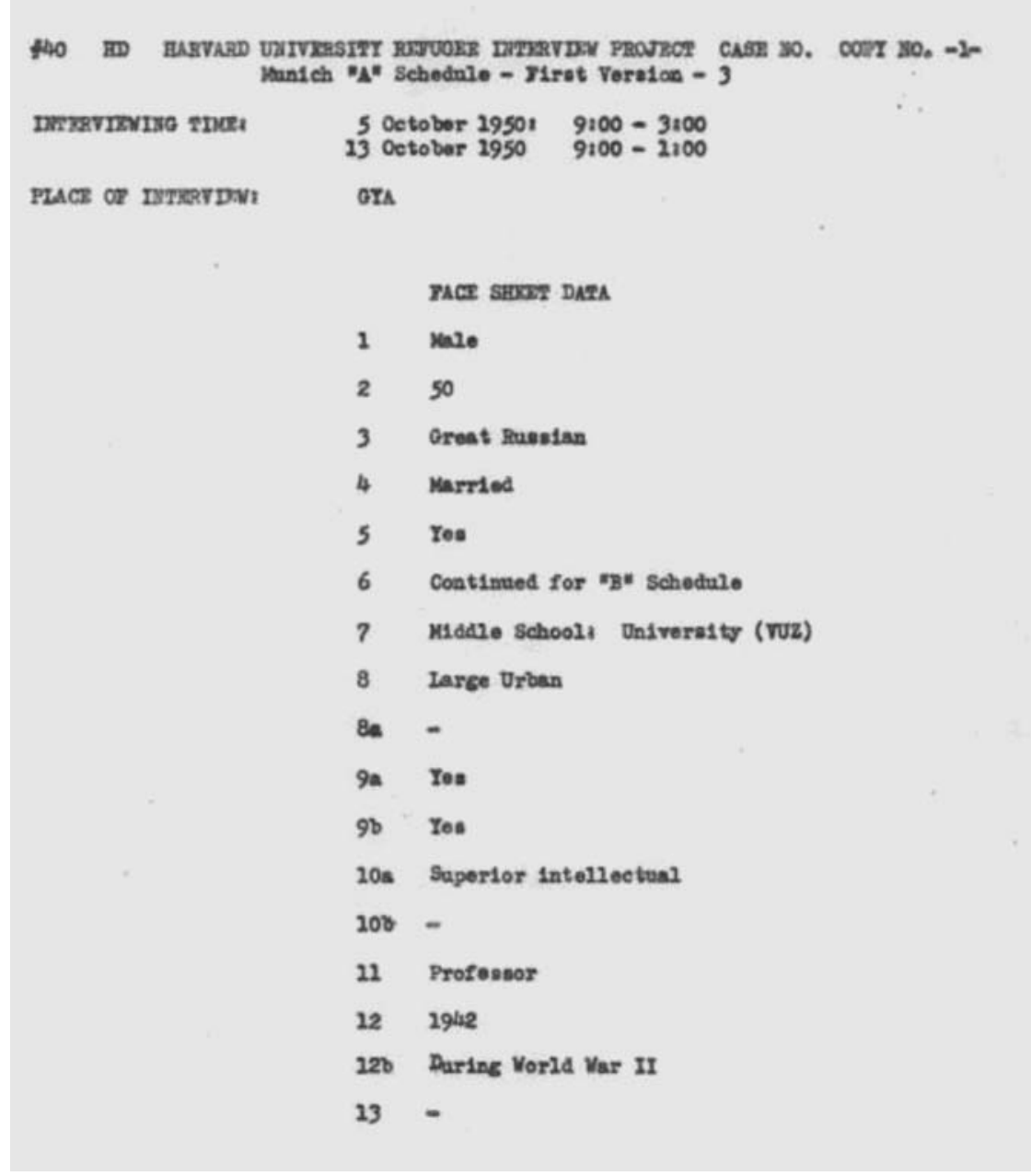

3. kép: Személyes adatok (Face Sheet Data), A-Schedule, Vol. 4, Case 40

B-Schedule, Vol. 2, Case 359. A rövid, kivonatszerủ dokumentumból nem sok mindent tudhatunk meg, vélhetően egy hosszabb interjú állt mögötte, de ennek nincsen nyoma az adatbázisban. 
a szakmákra vonatkozó kategóriában fennmaradt szöveg tartozik ide. Mind a négy forrás karriertörténet és a szakma helyzetéről szóló narratíva, tehát egyfajta önreflexió és a pályaív értékelése, ami biztosan belejátszott a mondanivalóba.

Az első példám egy 50 éves professzor és kutatóintézet-vezető profilja, ${ }^{10}$ a 3 . kép az életútinterjúk első oldalát, a személyes adatok felvételét mutatja be.

Az életkor, nemzetiség jelzése mellett többek között a családi állapot, végzettség, lakóhely, beosztás, a Szovjetunió elhagyásának dátuma szerepel. Az interjút két ülésben vették fel, a második nap, irányított kérdések után beszélt a professzor a szovjet pszichiátriáról - az amerikai szakértő nem tartotta teljesen megbízhatónak az információkat, bár megjegyezte, hogy szovjet beszélgetőpartnere nagyon tájékozott ezekben a kérdésekben. A professzor felvázolta kihallgatójának az orosz-szovjet pszichiátria rövid fejlödéstörténetét, a kiindulópont természetesen a pavlovi reflexológia volt (megjegyzése szerint ennek jelentőségét az USA-ban nem ismerik el eléggé). A Pavlov által alapított idegélettani iskola később kétfelé ágazott: a diagnosztizáló, esetekkel foglalkozó neuropatológia és a pszichiátria irányába - a sztálini időszak oktatásában pedig (fóleg a didaktikában) a kondicionálás logikáját használták fel. Kialakult a belgyógyászat és a mentális rendellenességekkel foglalkozó diszciplína közeli kapcsolata, majd fokozatosan újra egy kezelési rendszerben egyesült a fizikai és elmekórtani kezelés, neuropatológia és pszichiátria, ez pedig már Szperanszkij nevéhez füződik, aki alapkönyvet írt az idegrendszer és megbetegedések kapcsolatáról 1935-ben, újra szintézisben látva a kezelés tárgyát (Speransky 1943).

Behtyerev a pavlovi iskolával vetélkedve, szintén a feltételes reflexre alapozva dolgozott ki egy mechanisztikus elméletet, ${ }^{11}$ akárcsak az ukrán Volkov (másik nevén Lifsitz), akinek müvét (Reflex a kriminológiában) a Párt antileninistának és trockistának nevezte. A fö gond a könyv rossz oksági láncolata volt: a bűnözés biológiai eredete hamis, nem marxista elképzelésnek bizonyult, hiszen a kapitalista berendezkedés, a társadalmi faktor a döntő ebben (legalábbis az ideológiai nézőpont szerint). Ugyanaz a determinista szemlélet, közvetlen ok-okozati kapcsolat mutatható ki a biológiai és társadalmi alap feltételezésénél, de Volkov rossz tényezőre helyezte a hangsúlyt, hamarosan eltünt, csakúgy, mint zsidó munkatársa (nem volt véletlen az eredeti, Lifshitz névre való utalás). Egy érdekes bekezdésben Nyecsajevet, a pedológia fö képviselőjét (Minkova 2012; Illés-Albert 2020) teszi nevetségessé a válaszadó - kicsit mintha ez lenne az a „vörös farok", ami inkább a szovjet illetékeseknek szólt. A NEP alatti furcsa teóriaként említi Nyecsajev könyvét pszichiátria és testnevelés kapcsolatáról, amiben szerinte a szerző (aki egyébként a pedológiai mozgalom neves képviselője volt és nem összetévesztendő az anarchista forradalmár Nyecsajevvel) a foci ellen szólalt fel, mivel aki a labdát rúgja, előbb-utóbb a macskájával is ugyanezt fogja tenni. A reflexológia egyszerü ok-okozati logikáját kigúnyolta a professzor, de ugyanezt marxista köntösben már nem tette meg, mint korábban láttuk.

Ezt követően egy depressziós ember átlagos kezelési módjáról faggatta az amerikai kérdező a szovjet professzort, amit poliklinikai módszerként (poli-clinic methods) írt le a szöveg. A teljes szervi és reflexológiai kivizsgálást mindenfajta fizikai beavatkozás egé-

10 A-Schedule, Vol 4, Case 40.

11 Behtyerev előbb meghalt, mint Pavlov - Pavlov neve és nézetei lettek dominánsak a harmincas évektől, a politika által kiforgatva és átértelmezve. 
szítette ki (elektrosokk, röntgenes kezelések, hőmérséklet megváltoztatása, nyugtatózás) és a páciens folyamatos biztosítása arról, hogy minden rendben volt és lesz. A teljes beszélgetés summázataként leírásra került, hogy a szovjet pszichiátria inkább közel áll a sebészeti szemlélethez, az idegi betegségeket fizikai elváltozásokban szemléli és nem különíti el a különböző területeket: a tiszta pszichiátria (mint például a pszichoanalízis) antimaterialista és nem megengedett a Szovjetunióban. A tudásterület megnevezése vagy a specializálódással és szakmaisággal kapcsolatos attitűdök egyértelmüen politikai kérdésnek számítottak, akár pszichotechnikáról, akár neuropatológiáról volt szó, vagy összefoglaló néven pszichiátriáról.

A következő pszichiáter interjúalany, egy ötvenes éveiben járó nő nagyon ideges volt a beszélgetés alatt, ${ }^{12}$ félt, hogy az információi szovjet kezekbe jutnak, ez a feszült lelkiállapot a lejegyzett beszélgetésre is hatást gyakorolt. Az 1927 és 1940 között a kijevi Pszichiátriai és Neurológiai Intézetben dolgozó orvosnő nagyon általános dolgokat érintett, amelyekből nem lehetett baja később, egyetlen kitétel érint érzékenyebb területet az interjúban. 1929-ben egy bizottság mindenkit falura küldött dolgozni az intézetből, ezt ő megtagadta a családja miatt, így politikai engedetlenségért kirúgták, majd egy év múlva visszavették - ez a rövid epizód is mutatja, hogy milyen tapasztalatok miatt félhetett az orvosnő. A harmadik, valószínüleg férfi alany (róla még kevesebbet tudhatunk, mint az előző két interjúalanyról) hasonló klinikán dolgozott, ${ }^{13}$ az általa elégtelennek ítélt orvosi felkészítés után került be ide, ahol a rosszul alvó páciensektől a skizofréniás esetekig mindenkivel kellett foglalkoznia - később kiderül, hogy minden traumatikus reakciót skizofréniásként definiáltak, ami sokat elárul a kezelési gyakorlatról, ahol az elmondás szerint a hipnózistól az arzénes terápiáig sokmindent felhasználtak.

$\mathrm{A} z$ NKVD gyakran kért információkat a páciensekről, az adatok közlése vagy viszszatartása pedig bizonyos hatalmat adott az orvosok kezébe: voltak esetek, amikor elhallgattak dolgokat, máskor viszont félelemből, egyéb érdekektől vezetve bizalmas információkat árultak el. A csekisták rossz pszichikai állapotáról, mentális torzulásaikról szintén megemlékezik a forrás (más dokumentumok is megemlítik ezt, részletek nélkül) - nem véletlen ez a kitérő, mert aki idekerült, az privilegizált helyzetű, többségében párttag volt. Az amerikai kikérdező természetesen kapva kapott az információn és a szűkszavú válaszokból kiderítette, hogy egy előzetes szürővizsgálat engedélyezte, ki kaphat pszichiátriai kezelést, ami ellentmondott a korábban sugalltaknak és a több forrás által említett általános, mindenki számára elérhető orvosi ellátás eszméjének, etikájának, a modernizációs legitimáló narratívának.

A politika egyéb szinteken is behatolt az orvosi munkába: 1927 és 1930 között sok hisztériás és neurotikus tüneteket produkáló beteg került be, akik korábban hittek a forradalomban, részt vettek a rendszer kiépítésében, de a felépült sztálinizmus valósága traumatizálta őket. Ők mindig párttagok voltak, általában valamilyen krízisszituáció után kezdték meg a kezelést: egy bútorgyár igazgatója például hallucinációk (az általa meggyilkolt ellenforradalmárok képei) elől menekült a klinikára. Számos hasonló epizódot mesélt még el az orvos, ami a kommunista / szovjet rendszer egy kevéssé kutatott témájára, a pszichére tett hatások, lelki torzulások vizsgálatára hívja fel a figyelmet.

12 A-Schedule, Vol. 11, Case 139.

13 B-Schedule, Vol. 21, Case 139. 
Különbség volt párttag és nem párttag orvosok között is, vezető beosztásokba csak az előzők kerülhettek, de ezt természetesként fogadta el mindenki, akárcsak azt az orvosi rendszert, amiben szocializálódtak. Ezért érte őket a válaszadó szerint villámcsapásként, mikor egy lengyel szakmunka került a kezükbe, ami az elektrosokk elavultságáról írt - ők ezt a modernnek vélt eszközt ekkor kezdték el csak használni. A külföldtől való elzártságot sem észlelték korábban, ami egy újabb problémára hívja fel a figyelmet: a megszokott értelmezési keretek átfordítása és az összehasonlítás munkája nem feltétlenül volt magától értetődő mindenki számára.

Az egyetemeken nem orvosokat, hanem szovjet orvosokat képeztek („Nem lehet orvos valaki anélkül, hogy ne lenne leninista”), amit a sok ideológiai tantárgy is tükrözött, valamint a csoportmunka kollektív jellege, ahogyan a negyedik, értelmiségi családból származó pszichiáter arról beszámolt. ${ }^{14} \mathrm{~A}$ régi, cári időkben kibocsátott és a húszas évek új orvosgenerációi számára ég és föld különbségét jelentették: az utóbbiak tudása sekélyesebb, módszerei uniformizáltabbak voltak, a betegek inkább a régi idők doktoraihoz fordultak, még ha ez esetleg hátrányos következményekkel is járhatott. Ez a pszichiáter számos szimulánssal találkozott, hiszen a börtön vagy munkatábor elől sokan menekültek a pszichózisba, akiket ő nem leplezett le, mivel osztályidegenként ő sem volt a rendszer kegyeltje. A velük való beszélgetés tapasztalatait így foglalta össze a beszélgetés végén: a skizofréniás reakciók, fóbiák egy jelentős része a szovjet élet eredménye - de ezt nem tudta tudományosan alátámasztani.

\section{Befejezés}

Talán a legfontosabb levonható tanulság a pszichológia, pszichiátria és egyéb neveken illetett diszciplínák önállósághiánya (akár a pedagógia, gazdaság szolgálatában a tesztelés esetében, akár más céloknak való alárendeltségben), a politikai logika és ideológia több szinten való beavatkozása a szakmai, tudományos munkába. Ezt természetesen más szakmunka is bemutatta már (egy másik időszakot és helyet vizsgál: Kovai 2016), a legfontosabb specifikuma a vizsgálatomnak az elemzés alapjául választott korpusz. A bemutatott forrásbázis nem túl nagy, viszont nagyon fontosnak tartom a HPSSS felhasználását (a felvetett további kutatási irányokkal, például az interjúzás pszichológiai dimenzióval együtt), hiszen az 1945 elötti szovjet korszak tárgyalásakor a hivatalos dokumentumok, párthatározatok, szakcikkek dominálnak, és kevés olyan kortárs szöveg van, ami (ha áttételesen ugyan, de) a társadalomtörténet hétköznapi valóságáról számol be. A hidegháborús kontextus és az amerikai látószög további sajátos értelmezést és dinamikát ad a szövegeknek, ami újra és újra felhívja a figyelmet a forráskritika és módszertan kérdéseire - az elméleti újragondolás kényszerű hangsúlya pedig újabb pozitív következménye a hasonló gyüjteményekre, oral bistory anyagokra alapozó elemzéseknek.

14 B-Schedule, Vol. 21, Case 424. 


\section{FORRÁSOK}

\section{Interjúk}

Valamennyi interjú forrása: https://library.harvard.edu/col2lections/hpsss/index.html [Letöltve: 2020. 07. 25.]

B-Schedule, Vol. 2, Case 359.

B-Schedule, Vol. 2, Case 382.

B-Schedule, Vol. 13.

B-Schedule, Vol. 13, Case 374.

B-Schedule, Vol. 21, Case 39.

A-Schedule, Vol. 4, Case 40.

A-Schedule, Vol. 11, Case 139.

B-Schedule, Vol. 21, Case 139.

B-Schedule, Vol. 21, Case 424.

\section{Egyéb források}

A-Schedule Face Sheet Data Book. https://iiif.lib.harvard.edu/manifests/view/drs:5650830\$1i [Letöltve: 2020. 07. 23.]

Bauer, A. H. (1953) A Guide for Interviewing Soviet Escapees. Alabama, Maxwell AFB. https://iiif.lib.harvard.edu/manifests/view/drs:5420185\$1i [Letöltve: 2020. 07. 23.]

Guide to the Paul Friedrich Papers, 1945-1999. Chicago, University of Chicago Library, 2015. https://www.lib.uchicago.edu/e/scrc/findingaids/view.php?eadid=ICU.SPCL. FRIEDRICHP [Letöltve: 2020. 07. 23.]

Mandelstam, M. B. (1980) Materials for the Project on the Soviet Social System: Guide. Cambridge, MA, Russian Research Center, Harvard University. https://iiif.lib.harvard. edu/manifests/view/drs:6493998\$1i [Letöltve: 2020. 07. 23.]

Qualitative File Manual of B-Schedule Materials and Friedrich-Fainsod Materials (1953) https://iiif.lib.harvard.edu/manifests/view/drs:5647538\$1i [Letöltve: 2020. 07. 23.]

\section{IRODALOM}

Bailes, K. E. (1977) Alexei Gastev and the Soviet Controversy over Taylorism, 1918-24. Soviet Studies, Vol. 29. No. 3. pp. 373-394.

Balog B. \& Szabolcs É. (2019) Narratíva és pedagógiatörténet. Pedagógiatörténeti Szemle, Vol. 5. Nos 1-2. pp. 57-65.

Bauer, R. A., Inkeles, A. \& Kluckhohn, C. (1956) How the Soviet System Works. Cambridge, MA, Harvard University Press.

Edele, M. (2007) Soviet Society, Social Structure and Everyday Life. Kritika, Vol. 8. No. 2. pp. 349-373.

Engerman, D. C. (2009) Know Your Enemy. New York, Oxford University Press.

Fenete F. (1940) Az ember és a munka. Korunk, Vol. 15. No. 7-8. pp. 596-604.

Field, M. G. (1957) Doctor and Patient in Soviet Russia. Cambridge (MA), Harvard University Press.

Illés A. Zs. \& Albert B. G. (2020) Kegyvesztett pedológusok. Képzés és Gyakorlat, Vol. 18. Nos 1-2. pp. 47-54. 
Inkeles, A. \& Bauer, R. A. (1959) The Soviet Citizen. Cambridge (MA), Harvard University Press.

Kovar M. (2016) Lélektan és politika. Budapest, KRE-L'Harmattan.

Leopoldoff, I. (2014) A Psychology for Pedagogy. History of Psychology, Vol. 17. No. 3. pp. 187-205.

Minkova, E. (2012) Pedology as a Complex Science Devoted to the Study of Children in Russia. Psychological Thought, Vol. 5. No. 2. pp. 83-98.

Ognyev, N. (1977) Kosztya Rjabcev naplója. In: Vág O. (ed.) A marxista pedagógia története dokumentumokban III. Budapest, Tankönyvkiadó. pp. 97-105.

Pipes, R. (1979) How the Soviet Union is Governed, by Jerry F. Hough and Merle Fainsod. Commentary, October 1979. https://www.commentarymagazine.com/articles/richardpipes-2/how-the-soviet-union-is-governed-by-jerry-f-hough-and-merle-fainsod/ [Letöltve: 2020.07 .23$.

PléH Cs. (2011) A pszichológia mint a nevelés eszmei hivatkozási kerete. Educatio, Vol. 20. No. 1.pp. 18-36.

Prendergast, S. (2017) Revisiting the Harvard Project on the Soviet Social System. Oral History Review, Vol. 47. No. 1. pp. 19-38.

SÁska G. (2011) Az új társadalomboz új embert és új pedagógiát! Budapest, Gondolat.

SÁsKa G. (2015) A pedagógiai normák változása az 1920-as 30-as évek Szovjet-Oroszországában. Pedagógiatörténeti Szemle, Vol. 1. No. 1. pp. 31-52.

Skoromets, A. A. \& Akimenko, M. A. (2007) The History of Neurology in St. Petersburg. Journal of the History of the Neurosciences, Vol. 16. Nos 1-2. pp. 90-99.

Speransky, A. D. (1943) A Basis for the Theory of Medicine. New York, International Publishers.

Tamura, E. H. (2011) Narrative History and Theory. History of Education Quarterly, Vol. 51. No. 2. pp. 150-157.

This is Your Air Force (1951) Air Reserve Forces Review, January 1951, p. 15.

Tureby, M. T. (2013) To Hear with the Collection. Oral History, Vol. 41. No. 2. pp. 63-74. Zamjatrin, J. (2008) Mi. Budapest, Cartaphilus.

A cikk a Creative Commons Attribution 4.0 International License (https://creativecommons.org/licenses/ by/4.0/) feltételei szerint publikált Open Access közlemény, melynek szellemében a cikk bármilyen médiumban szabadon felhasználható, megosztható és újraközölhető, feltéve, hogy az eredeti szerző és a közlés helye, illetve a CC License linkje és az esetlegesen végrehajtott módosítások feltüntetésre kerülnek. (SID_1) 